\title{
A systems approach framework for coastal management and its application in practice
}

\author{
Miguel Inácio ${ }^{1,2} \cdot$ Georg Umgiesser ${ }^{1,3}$ \\ Received: 10 July 2019 / Accepted: 10 July 2019/Published online: 10 September 2019 \\ (C) Springer Nature B.V. 2019
}

\section{Importance of coastal ecosystems}

Considered as one of the most productive systems worldwide, supporting a wide array of habitats and species, coastal ecosystems are also important drivers of human wellbeing and development (Costanza et al. 1997). With more than $60 \%$ of the world's population living at the coast (Turner et al. 2014), people depend on a healthy and fully functioning ecosystem to provide goods and services (Millennium Ecosystem Assessment 2005). However, to cope with population growth, the increasing demand for ecosystems goods and services has led, in general, to uncontrolled and unsustainable use of natural resources (Secretariat of the Convention on Biological Diversity 2010), resulting in the environmental degradation and loss of coastal ecosystems (Millennium Ecosystem Assessment 2005). While initially carried out in a sectorial way (managing different pressures individually), the complex multitude of anthropogenic uses both from land and sea requires that the management of coastal ecosystems is undertaken in a holistic and integrative approach (managing several pressured inclusively) (Apitz et al. 2006).

Miguel Inácio

miguel.inacio@io-warnemuende.de

Georg Umgiesser

georg.umgiesser@ismar.cnr.it

1 Marine Research Institute, Klaipeda University, Klaipeda, Lithuania

2 Leibniz Institute for Baltic Sea Research Warnemünde, Rostock, Germany

3 Consiglio Nazionale delle Ricerche, Istituto di Scienze Marine (CNR-ISMAR), Venice, Italy

\section{A major step in the direction of integrated coastal management}

The adoption of Integrated Coastal [Zone] Management (ICZM) in the US (Knecht and Archer 1993), and later in Europe (EC 2000), was a major step in the direction of integrative approach to management and the wide application of the concept in several policies, research projects and frameworks at different spatial scales (Shipman and Stojanovic 2007) contributed to a better understanding and management of complex problems related to coastal conflicts. However, gaps and pitfalls related to the difficulty in translating the principles of ICZM into practice, the insufficient political and legal status, the lack of a consistent and applicable process for practitioners and policymakers and the insufficient monitoring of the proposed goals (Shipman and Stojanovic 2007; Soriani et al. 2016), led to the exploration of ways to further refine the structured approach to coastal management.

\section{The systems approach framework (SAF)}

To this end the EU-funded project SPICOSA (Science and Policy Integration for Coastal Systems Assessment, EU 6th, Nr. 036992) developed a new approach, The Systems Approach Framework (SAF), based on the Systems Theory (Von Bertalanffy 1968) which requires a holistic view focusing on the relationships between components of a system. The SAF was then tailored to provide a structured method for ICZM ensuring a holistic (ecosystem-based) approach, dealing with complex systems in a multidisciplinary way by including environmental, socio-economic and cultural elements (Hopkins et al. 2011). The application of SAF to multiple case studies around Europe revealed its capacity to address multiple issues simultaneously, implement transdisciplinary science and to mobilize the best knowledge to support ICZM 
policies (Hopkins et al. 2011, 2012) by using model-based scenario simulations to serve as a basis to promote interaction with stakeholders (Gillgren et al. 2018). Newton (2012, p.1) describes SAF as "not a strict methodology, it is truly a framework that can be used and adapted to different coastal systems, different issues, different stakeholders, and different countries". However, the wide application of SAF also revealed its limitations. The lack of supportive tools for stakeholder engagement, and complexity in the terminology used in the approach as well as the weak inclusion of all parties interested, including citizens (Hopkins et al. 2012). Most importantly, what was lacking in the SAF process were the implementation and monitoring steps, necessary in the context of policy implementation and decision-making.

\section{The new systems approach framework (SAF) and its practical application}

To overcome these limitations and to aim at effectively addressing mainstream policies and approaches dealing with coastal management, SAF needed to be revisited and reformulated. To this end, this Special Issue of the Journal of Coastal Conservation introduces an improved and refreshed version of the SAF, the product of the work developed under the research project BONUS BaltCoast (A Systems Approach Framework for Coastal Research and Management in the Baltic) (www.baltcoast.net). The developments made within the BONUS BaltCoast project aim to enhance science-policy integration and prevent stakeholder fatigue (Gillgren et al. 2018). In this Special Issue, Støttrup et al. (2019) describes in detail the new version of the SAF. The original five steps were revised and merged into four: the Issue Identification, System Design, System Formulation and System Assessment (Støttrup et al. 2019). Furthermore, aiming at closing the loop of a complete ICZM measure, the new SAF introduces two more steps, the Implementation and the Monitoring and Evaluation steps, which aim at "helping to strengthen the science-policy integration, secure appropriate monitoring and evaluation, and maintain stakeholder participation" (Støttrup et al. 2019). Each step has now a concrete and comprehensive list of action to be taken assisted by a set of decision support tools and frameworks, especially in the framework of SAF.

This Special Issue also tests the new SAF process through several case studies comprised of the BONUS BaltCoast project: in Schernewski et al. (2017) to explore the possibility, together with stakeholders, to open a beach in the Curonian Lagoon (Lithuania); in Schernewski et al. (2018) the SAF is applied to evaluate the effects of three potential scenarios of Zebra mussel (Dreissena polymorpha) cultivation in the Oder Lagoon (Germany) in an ecological-social-economic context; in Tõnisson et al. (2018), to support coastal zone management in Pärnu (Estonia) by (re)evaluating coastal protection and flood prevention measures; and in Dinesen et al. (2019) to support sustainable fisheries management by understanding the decline of Atlantic cod (Gadus morhua) fishery in Danish waters. Highlighted by Gillgren et al. (2018), in the SAF application, an effective public participation strategy is of great importance to support the process of policy implementation and decision-making.

The information, experiences and lessons learned within the BONUS BaltCoast project, were transcribed into the development of a SAF Handbook, which is freely available online on a dedicated website as ELearning material (www.safhandbook.net).

Acknowledgements The studies comprised in this Special Issue were primarily funded by the BONUS BaltCoast Project. BONUS BaltCoast has received funding from BONUS (Art 185) funded jointly from the European Union's Seventh Programme for research, technological development and demonstration, and from Baltic Sea national funding institutions.

\section{References}

Apitz SE, Elliott M, Fountain M, Galloway TS (2006) European environmental management: moving to an ecosystem approach. Integr Environ Assess Manag 2:80-85. https://doi.org/10.1002/ieam.5630020114

Costanza R, Arge R, De Groot R, Farber S, Grasso M, Limburg K, Naeem S, O'Neill RV, Paruelo J, Raskin RG, Sutton P, Van den Belt M (1997) The value of the world's ecosystem services and natural capital. Nature 387: 253-260. https://doi.org/10.1038/387253a0

Dinesen G, Neuenfeldt S, Kokkalis A, Lehman A, Egekvist J, Kristensen K, Munk P, Hussy P, Støttrup J (2019) Cod and climate: a systems approach for sustainable fisheries management of Atlantic cod (Gadus morhua) in coastal Danish waters. J Coast Conserv

EC (2000) Communication from the commission to the council and the European Parliament on integrated coastal zone management: a strategy for Europe. Off J Eur Union COM (2000):27. https://doi. org/10.1017/CBO9781107415324.004

Gillgren C, Støttrup JG, Schumacher J, Dinesen GE (2018) Working together: collaborative decision making for sustainable integrated coastal management (ICM). J Coast Conserv. https://doi.org/10. 1007/s11852-018-0631-z

Hopkins T, Bailly D, Støttrup J (2011) A systems approach framework for coastal zones. Ecol Soc 16(4):25. https://doi.org/10.5751/ES04553-160425

Hopkins TS, Bailly D, Elmgren R, Glegg G, Sandberg A, Støttrup J (2012) A systems approach framework for the transition to sustainable development: potential value based on coastal experiments. Ecol Soc 17(3):39. https://doi.org/10.5751/ES-05266-170339

Knecht RW, Archer J (1993) 'Integration' in the US coastal zone management program. Ocean and Coast Manag 21:183-199. https://doi. org/10.1016/0964-5691(93)90026-U

Millennium Ecosystem Assessment (2005) Ecosystems and human wellbeing: synthesis. Island press, Washington, D.C.

Newton A (2012) A systems approach for sustainable development in coastal zones. Ecol Soc 17(3):41. https://doi.org/10.5751/ES-04711-170341

Schernewski G, Baltranaitė E, Kataržytė M, Balčiūnas A, Čerkasova N, Méžinė J (2017) Establishing new bathing sites at the Curonian lagoon coast: an ecological-social-economic assessment. J Coast Conserv. https://doi.org/10.1007/s11852-017-0587-4 
Schernewski G, Friedland R, Buer AL, Dahlke S, Drews B, Höft S, Klumpe T, Schadach M, Schumacher J, Zaiko A (2018) Ecological-social-economic assessment of zebra-mussel cultivation scenarios for the Oder (Szczecin) lagoon. J Coast Conserv. https:// doi.org/10.1007/s11852-018-0649-2

Secretariat of the Convention on Biological Diversity (2010) Ecosystem goods and Services in Development Planning: a good practice guide. Montréal, Canada

Shipman B, Stojanovic T (2007) Facts, fictions, and failures of integrated coastal zone Management in Europe. Coast Manag 35:375-398. https://doi.org/10.1080/08920750601169659

Soriani S, Buono F, Camuffo M (2016) Problems and pitfalls in ICZM implementation: lessons from some selected Mediterranean and Black Sea cases. Journal of Coastal Zone Management s1:1-7. https://doi.org/10.4172/2473-3350.1000s1-002

Støttrup JG, Dinesen GE, Schumacher J, Gillgren C, Inácio M, Schernewski G (2019) The systems approach framework for collaborative, science-based management of complex systems. J Coast Conserv. https://doi.org/10.1007/s11852-018-00677-5

Tõnisson H, Kont A, Orviku K, Suursaar Ü, Rivis R, Palginõmm V (2018) Application of system approach framework for coastal zone management in Pärnu, SW Estonia. J Coast Conserv. https://doi.org/ 10.1007/s11852-018-0637-6

Turner K, Schaafsma M, Elliott M, Burdon D, Atkins J, Jickells T, Tett P, Mee L, van Leeuwen S, Barnard S, Luisetti T, Paltriguera L, Palmieri G, Andrews J (2014) UK National Ecosystem Assessment Follow-on. Work Package Report 4: Coastal and marine ecosystem services: principles and practice. UNEP-WCMC, UK

Von Bertalanffy L (1968) General system theory, 1st edn. Georg Braziller, New York

Publisher's note Springer Nature remains neutral with regard to jurisdictional claims in published maps and institutional affiliations. 